\title{
When Environmental Chemistry Meets Ecotoxicology: Bioavailability of Inorganic Nanoparticles to Phytoplankton
}

\author{
Vera I. Slaveykova*, Mengting Li, Isabelle A. Worms, and Wei Liu
}

\begin{abstract}
The present review critically examines the state-of-the-art of the research concerning the likely environmental implications of engineered nanoparticles (ENPs) with specific emphasis on their interactions with phytoplankton in the aquatic environment. Phytoplankton plays a key role in the global carbon cycle and contributes to the half of the global primary production, thus representing some of the Earth's most critical organisms making the life on our planet possible. With examples from our own research and the literature, we illustrate what happens when aquatic organisms are unintentionally exposed to metal-containing ENPs, which are increasingly released into the environment from nano-enabled materials. We highlight the complexity of the ENPs behavior in the aquatic environment and focus on the three key steps of the bioavailability process: exposure availability, uptake availability and toxico-availability. The influence of the phytoplankton on the ENPs fate in the aquatic environment is discussed, too.
\end{abstract}

Keywords: Bioavailability $\cdot$ Engineered nanoparticles $\cdot$ Nanotoxicology $\cdot$ Phytoplankton $\cdot$ Water

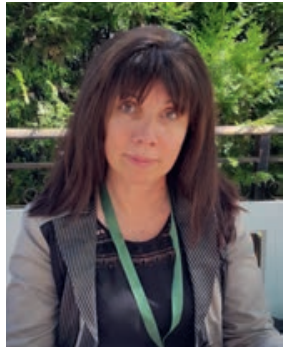

Dr. Vera I. Slaveykova is a professor of environmental biogeochemistry and ecotoxicology at the University of Geneva, and Vice-President of the Section Earth and Environmental Sciences. She works on development of novel concepts and tools for a better understanding of fundamental processes governing behavior and impacts of trace elements and nanoparticles, their interactions with various biotic and abiotic constituents of aquatic systems. Her research interests and portfolio include: (i) speciation and bioavailability of trace elements and nanoparticles in the aquatic environment; (ii) aquatic toxicology of inorganic contaminants and nanoparticles; transcriptomics and metabolomics; (iii) community ecotoxicology and biodiversity in aquatic systems.

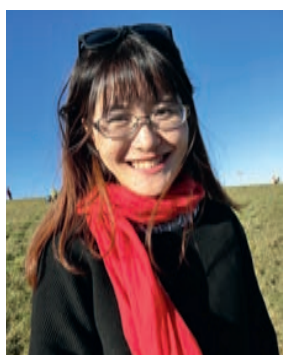

Mengting $\mathbf{L i}$ obtained her Master's degree in environmental engineering from the Chinese Academy of Sciences. Currently she is a PhD student in the laboratory of Environmental Biogeochemistry and Ecotoxicology at the University of Geneva. She studies (i) the physico-chemical interactions between titanium dioxide nanoparticles and inorganic/organic mercury species in freshwaters and (ii) cocktail effects of mixtures of titanium dioxide nanoparticles and inorganic/organic mercury to phytoplankton and zooplankton.

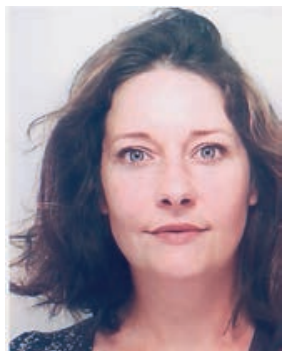

Dr. Isabelle A. M. Worms is a senior scientist of environmental chemistry and ecotoxicology at the University of Geneva. She is working on the development of new techniques to assess the interactions of trace metals and metallic nanoparticles with environmental components, such as small ligand, natural colloids, biota. Her recent development includes the optimization of asymmetrical flow field-flow fractionationICP-MS for quantification of metals bound to humic substances in complex environmental settings and the colloidal behavior of nanoparticles in the presence of (bio)ligands.

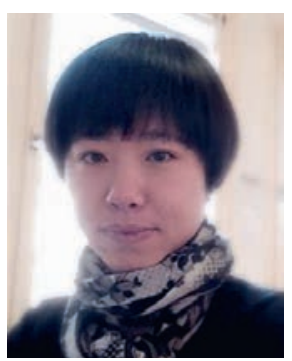

Dr. Wei Liu is a research and teaching fellow of biology and ecotoxicology at the University of Geneva. She received her $\mathrm{PhD}$ degree in Environmental science in 2009 from the University of Provence, France. From 2010 to 2017, she worked as a researcher at the European Center for Research and Education in Environmental Geoscience and France Alternative Energies and Atomic Energy Commission. Her research interests include: (i) characterization of environmental fate and distribution of different forms of inorganic pollutants, including dissolved metal species, natural and manufactured nanomaterials; (ii) identification of biomolecule/nanoparticles interaction; (iii) (eco)toxicology of pollutants at molecular, cellular and organism scale. 


\section{Introduction}

Nanotechnology is considered as "the sixth truly revolutionary technology introduced in the modern world". [1] Nanotechnology is based on engineered nanoparticles (ENPs), novel entities with significantly enhanced electrical, mechanical, optical, chemical properties at nanoscale. ${ }^{[2]}$ Hence, the purposely made engineered nanomaterials outperforming the traditional non-nanoparticle materials show a lot of promise for direct and indirect benefits in almost all spheres of modern society. Nanotechnology brings novel opportunities for the environment - from improved pollution sensors and water treatment procedures to pesticide replacements. ${ }^{[3]}$ However, it is not all good news given the serious concerns that some ENPs may have detrimental effects on the environment if present in significant quantities. ${ }^{[4]}$ For example, nanobiocides, such as AgNPs, CuONPs, were shown to be more toxic to non-target organisms than to targeted bacteria. ${ }^{[5]}$ Therefore, the big challenge is how to take advantage of the opportunities provided by the nano-enabled materials, while avoiding or mitigating associated environmental hazards and risks of ENP use. Addressing the above challenge requires rigorous analysis of the benefits versus risks. Such analysis needs to be underpinned by state-of-the-art tools for quantification and characterization of ENPs in complex environmental and biological settings, appropriate bioassays for reliable assessment of ENPs potential effects as well as suitable models for predicting their risks. More importantly, improved and quantitative understanding on the key processes' underling the interactions between the ENPs and living organisms is central for linking the exposure (usually addressed in environmental chemistry) and effects (usually addressed in ecotoxicology).

In such a context, the research of the Laboratory Environmental Biogeochemistry and Ecotoxicology of the University of Geneva aims to improve the understanding of the interactions of the ENPs with different biotic and abiotic components of the aquatic environment. We are using bioavailability or "the extent of adsorption of a substance by a living organism" [6] as a key concept allowing to quantitatively relate the changes in the contaminant concentra- tions and speciation with the intensity of the biological effects. The specific focus is on the phytoplankton given (i) its crucial role in the global elemental cycling; ${ }^{[7]}$ (ii) its significant contribution to half of global primary production ${ }^{[8]}$ and (iii) its key position at the bottom of the aquatic food webs.

In this review paper, we focus on two interconnected questions on the effects of ENPs on phytoplankton and the influence of phytoplankton on the ENPs' fate in the aquatic environment and discuss the key concept of bioavailability of ENPs. It is out of the scope of this article to provide a detailed overview on the fate and impact of the ENPs in the environment. Abundant information on the environmental implications of ENPs can be found in recent review papers. ${ }^{[9]}$

\section{Bioavailability of ENPs to Phytoplankton}

It is an important paradigm in ecotoxicology that a contaminant must be biologically available (bioavailable) to have significant effect on living organisms like phytoplankton. In the case of the ENPs, the bioavailability to phytoplankton is a result of several interconnected processes (Fig. 1) ${ }^{[10]}$ including: (i) transport of the ENPs from exposure medium to cellular surface, e.g. via diffusion (1, Fig. 1). This process is size-dependent and differs for dissolved, single ENPs and aggregates formed in the ambient medium; (ii) reversible adsorption of different ENPs forms (2, Fig. 1) on the cell walls and membrane; (iii) internalization (or not) by different mechanisms (3, Fig. 1), e.g. by endocytosis and phagocytosis and/or by altering the cell membranes; ${ }^{[9 c, 10 a, 11]}$ (iv) cellular distribution and transformation (4, Fig. 1) and (v) excretion (5, Fig. 1). Furthermore, bioavailability can be considered as three principal components:[12] 'exposure availability', 'actual or potential uptake availability', and 'toxico-availability'.

The bioavailability depends on multiple factors ${ }^{[10 a]}$ related with: (i) the type and characteristics of the ENPs, such as its physicochemical speciation, size, shape, surface functionalization etc.; (ii) the ambient water variables, such as $\mathrm{pH}$, water hardness and alkalinity; (iii) the presence and concentrations of other dissolved,

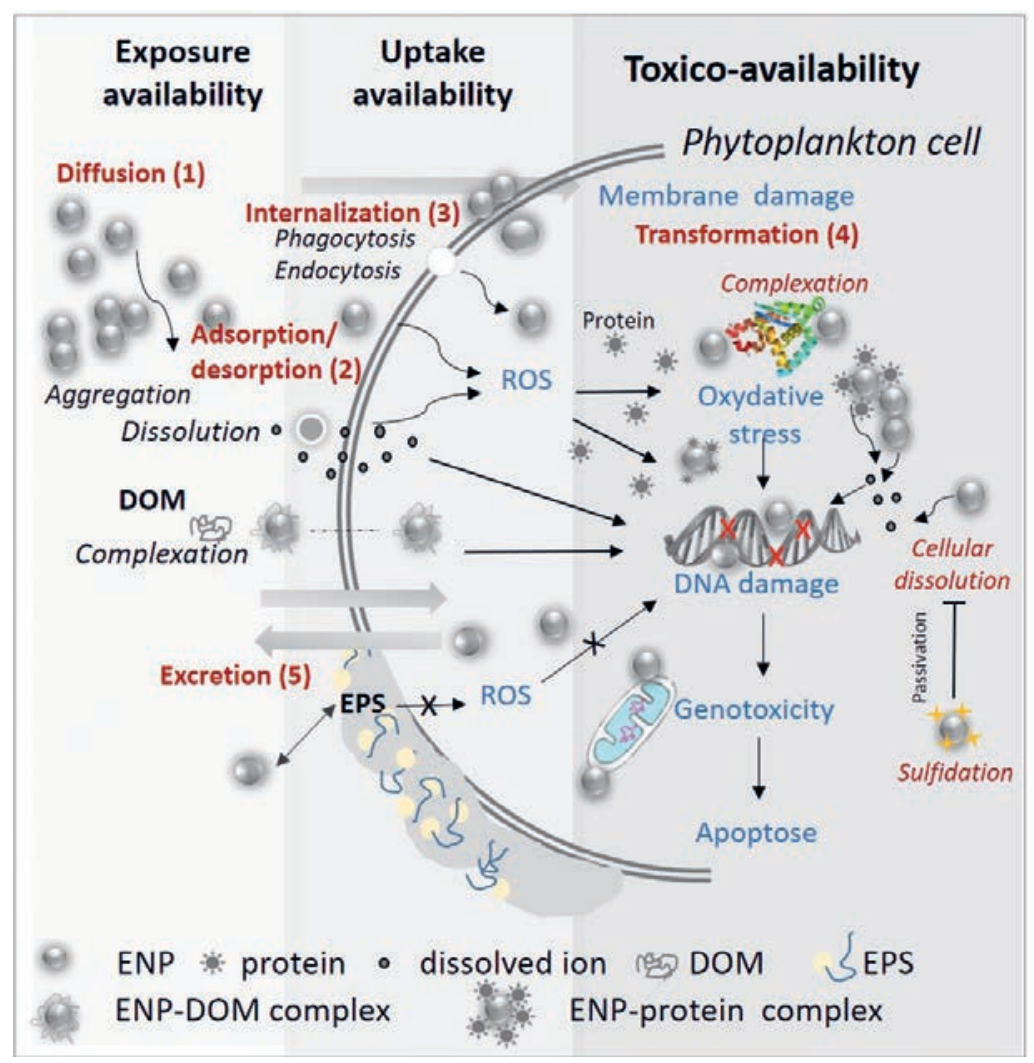

Fig. 1. Key processes at the ambient medium-phytoplankton interface that determine the ENPs bioavailability and the three bioavailability steps: exposure availability, uptake availability and toxico-availability. 
nanoparticulate and colloidal forms of contaminants; (iv) the presence and concentrations of different ligands from natural and anthropogenic origins, which may influence chemical and physicochemical speciation; (v) the phytoplankton characteristics, such as cell type, cell wall, cell membrane, differentiation stage and its pathways of particle uptake and cellular processing.

\section{How Do ENPs Affect the Phytoplankton in the Aquatic Environment?}

Addressing this question requires extensive understanding of different processes determining the exposure availability, the uptake availability, and toxico-availability.

\subsection{Exposure Availability}

In the specific case of phytoplankton, the forms of ENPs still dispersed in the water column are considered as available for exposure in contrast to the sedimented particles. Thus, the exposure availability is determined by the physicochemical speciation of the ENPs, which is a result of the interplay between aggregation, sedimentation and dissolution processes. ${ }^{[13]}$ These processes are modified by different physicochemical variables, including $\mathrm{pH}$, $\mathrm{O}_{2}$, light, ionic composition, nature and concentration of dissolved organic matter (DOM). ${ }^{[14]}$ The complexation of ENPs with different ligands, such as DOM, leading to the formation of particle's eco-corona and its stabilizing/destabilizing role in the ENPs suspensions was highlighted. ${ }^{[15]}$ The nature of the eco-corona could affect the ENPs behavior and bio-interactions, ${ }^{[16]}$ hence it is very important to take it into account in the evaluation of the exposure availability. The lack of process-based models, representing the particle size distribution and its dynamics in the exposure medium, and the dynamics of dissolution and aggregation were pointed out recently as an important challenge in the exposure assessment and modelling. ${ }^{[12]}$

\subsection{Uptake Availability of the ENPs}

Uptake availability refers to the ENPs' forms that can be adsorbed and internalized by the organism. ${ }^{[12]}$ Multiple examples demonstrate the adsorption of metallic and metal oxide nanoparticles (NPs) to freshwater microalgae. Platinum nanoparticles (PtNPs) were shown to adhere to the surface of the green algae Pseudokirchneriella subcapitata and Chlamydomonas reinhardtii, ${ }^{[17]}$ palladium $(\mathrm{Pd}) \mathrm{NPs}^{[17 \mathrm{~b}]}$ and four iron-containing particles ${ }^{[18]}$ to $C$. reinhardtii; silver (Ag) NPs to Euglena gracilis ${ }^{[19]}$ and $C$. reinhardtii, ${ }^{[17 \mathrm{~b}]}$ gold $(\mathrm{Au}) \mathrm{NPs}$ to the diatom Eolimna minima ${ }^{[20]}$ and $C$. reinhardtii. ${ }^{[17 b]}$ Titanium dioxide $\left(\mathrm{TiO}_{2}\right) \mathrm{NPs}$ aggregates trapped different phytoplankton species, including the green alga Raphidocelis subcapitata, the diatom Fistulifera pelliculosa, and the cyanobacterium Synechocystis sp. ${ }^{[9 f]}$ Similarly the $\mathrm{TiO}_{2} \mathrm{NPs}$ aggregates attached to $C$. reinhardtti, but the aggregate formation and pattern was $\mathrm{pH}$ dependent (Fig. 2).

The adsorption of the ENPs to cell surface was dependent on the composition of the cell wall. ${ }^{[10 a, 11,22]}$ Carboxyl-CdSe/ZnS quantum dots significantly adsorbed to a cell wall-less mutant of $C$. reinhardtii, while adsorption was minimal to the wildtype strain containing glycoproteins and no adsorption was observed to Chlorella kesslerii possessing a cellulosic cell wall.[23] Overall, the interactions of ENPs with proteins and polysaccharides of the cell wall and membranes seem to play an important role in actual or potential uptake of ENPs. However, these interactions have been poorly studied and should be subject of future research.

Endocytosis is accepted as a major pathway of entry of ENPs and was demonstrated in various phytoplankton species. [10a,11,24] For example, endocytosis was involved in the internalization of AgNPs by the golden-brown alga Ochromonas danica, ${ }^{[25]}$ thioglycolic acid stabilized CdTe quantum dots by $O$. danica, ${ }^{[26]} \mathrm{TiO}_{2} \mathrm{NP}$ by the blue-green alga Anabaena variabilis. ${ }^{[27]} \mathrm{TiO}_{2} \mathrm{NPs}^{[28]}$ and
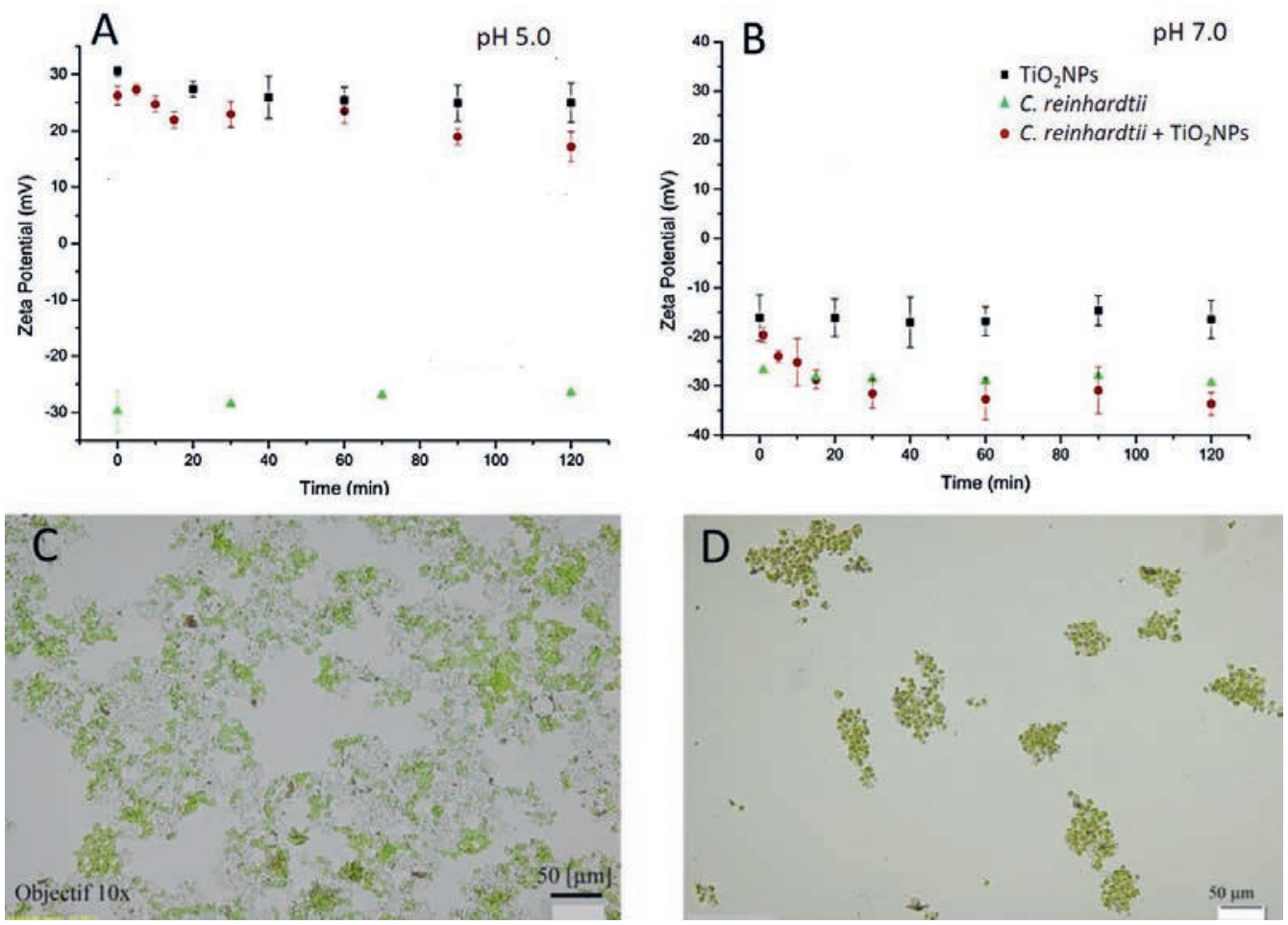

Fig. 2. $\mathrm{pH}$ dependence of the attachment of $\mathrm{TiO}_{2} \mathrm{NP}$ aggregates to the green alga Chlamydomonas reinhardtii. The zeta-potential of suspensions containing $\mathrm{TiO}_{2} \mathrm{NPs}$ (black squares), C. reinhardtii (green triangles) and C. reinhardtii and $\mathrm{TiO}_{2} \mathrm{NPs}$ (red dots) was measured at different exposure times at $\mathrm{pH} 5.0(\mathrm{~A})$ and $\mathrm{pH} 7.0(\mathrm{~B})$. $\mathrm{TiO}_{2} \mathrm{NPs}$ are positively charged at $\mathrm{pH} 5.0$, and negatively charged at $\mathrm{pH} 7.0$; whereas $\mathrm{C}$. reinhardtii is negatively charged at both pHs. At pH 5.0, the interaction of $\mathrm{TiO}_{2} \mathrm{NPs}$ with $\mathrm{C}$. reinhardtii results in changes of the sign of the Zeta-potential of the algae which became positive and closer to that determined in $\mathrm{TiO}_{2}^{2} \mathrm{NPs}$ suspensions. At pH 7.0, no significant changes in the Zeta-potential of $C$. reinhardtii were found. The presence of opposed charge between the ENPs and C. reinhardtii could promote the change of the surface's charge of algae and facilitate the surface adhesion of ENPs to the cells. These observations were consistent with bright field microscopy observation at $\mathrm{pH} 5.0(\mathrm{C})$ and $\mathrm{pH} 7.0$ (D). The figures are based on data from Sottocasa. ${ }^{[21]}$ 
copper oxide $(\mathrm{CuO}) \mathrm{NPs}^{[29]}$ were found in the cell wall and cytoplasm of $C$. reinhardtii. AuNPs were internalized by both the wild-type and the cell wall-deficient, $C$. reinhardtii strains.[30] AgNPs uptake was proposed to determine its toxicity to the marine microalga Phaeodactylum tricornutum, ${ }^{[31]}$ whereas AgNPs dissolution was the main toxicity factor in the other microalga C. reinhardtii. ${ }^{[31,32]}$ AuNPs dose- and time-dependent uptake was verified in Cyptomonas ovate ${ }^{[33]}$ and $\mathrm{CdTe} / \mathrm{CdS}$ quantum dots were taken up by $C$. reinhardtii. ${ }^{[34]}$ These selected examples illustrate that ENPs of different composition and sizes can penetrate the cell membranes of phytoplankton species. However, the exact mechanisms need further attention and the question whether the majority of phytoplankton species have specific mechanisms of ENPs uptake is still open. Furthermore, the phytoplankton cell walls are considered as efficient barriers, which prevent internalization of ENPs, thus the majority of the phytoplankton are often considered as particle-proof.[10a,35] Other possible mechanisms of ENPs penetration through the cell membrane/walls include uptake by non-specific diffusion, uptake by non-specific membrane damage, specific uptake or adhesive interactions. ${ }^{[10 a, 11,36}$ However further experimental evidence is necessary to confirm their relevance with respect to the phytoplankton species.

\subsection{Toxico-availability of ENPs}

"Toxico-availability" of ENPs includes "the biochemical and physiological processes resulting from the effects of the toxicant at the site of action". ${ }^{[12]}$ It is governed by the interactions with biomolecules essential for cellular functioning. ${ }^{[9 h, 37]}$ ENPs exhibit a potential to affect the phytoplankton directly and indirectly, via metal ion release and generation of reactive oxygen species (ROS) harmful to cells. ${ }^{[9 c, 38]}$ The generation of the excessive ROS by ENPs can be triggered by impurities, photoactivation, dissolution and interaction of ENPs with biomolecules. ${ }^{39]}$ The excessive intracellular ROS levels could damage lipids, proteins and DNA. ${ }^{[40]}$ The importance of the oxidative stress in ENPs ecotoxicity is well understood and comprehensively reviewed. ${ }^{[9 h, 10,41]}$ Here we will provide a few recent examples specific to phytoplankton species. Dichromium trioxide $\left(\mathrm{Cr}_{2} \mathrm{O}_{3}\right) \mathrm{NPs}$ induced excessive ROS formation and damage to the reaction center of photosystem II in the chloroplasts of $C$. reinhardtii. ${ }^{[42]}$ Zinc oxide $(\mathrm{ZnO}) \mathrm{NPs}^{[43]}$ and cobalt ferrite $\left(\mathrm{CoFe}_{2} \mathrm{O}_{4}\right) \mathrm{NPs}^{[44]}$ altered the activity of oxidative stress enzymes in Chlorella vulgaris. Similar observations were found for $\mathrm{TiO}_{2} \mathrm{NPs}_{\mathrm{s}}$ and several diatom species including Nitzschia closterium, ${ }^{[45]}$ Karenia brevis and Skeletonema costatum, ${ }^{[46]}$ and Scenedesmus sp. ${ }^{[47]}$ The enhanced ROS production was shown to depend on multiple factors ${ }^{[24]}$ including ENPs properties, organism properties and the ambient medium variables. For example, it was shown that the excessive ROS generation by $\mathrm{TiO}_{2} \mathrm{NPs}_{\mathrm{s}}$ is dependent on: (i) ENPs size, with a lower size exhibiting a stronger pro-oxidant effects; ${ }^{[48]}$ (ii) crystal structure, with anatase being more ROS reactive; [48] (iii) surface functionalization of the $\mathrm{TiO}_{2} \mathrm{NPs}$, as well as UV radiation activation. ${ }^{[49]}$ However, concentration- and primary size dependences of ENPs causing cellular oxidative stress are not always clearly seen (Fig. 3).

The oxidative stress potential of metal oxide nanoparticles to bacteria increased when the energy at the conduction band of the particle falls into the range of redox potentials of biological molecules together with having a less negative hydration enthalpy. ${ }^{[51]}$ However, whether this is valid in the case of phytoplankton species has to be elucidated. In addition, comparative studies with phytoplankton species showed that they differ according to their sensitivity to excessive ROS. For example, more than $90 \%$ of the cells of $C$. reinhardtii were stressed after $2 \mathrm{~h}$ exposure to 1 $\mathrm{mg} \mathrm{L}^{-1} \mathrm{Pt}$ of $2 \mathrm{~nm}$ starch-coated PtNPs, whereas under similar conditions only $25 \%$ of cells of $P$. subcapitata were affected.[17a] Interestingly, no significant oxidative membrane damage was

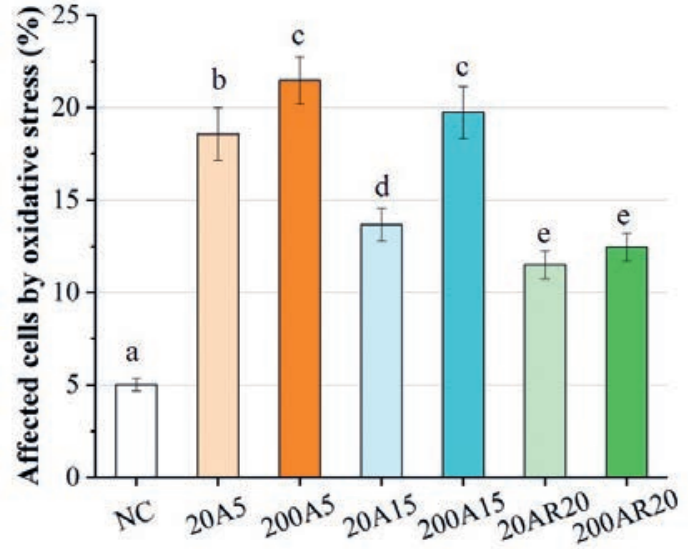

Fig. 3. Oxidative stress in Chlamydomonas reinhardtii exposed to $\mathrm{TiO}_{2}$ NPs. Percentage of cells exhibiting oxidative stress after $72 \mathrm{~h}$ exposure to 20 and $200 \mathrm{mgL}^{-1} \mathrm{TiO}_{2} \mathrm{NPs}$ of different primary sizes and crystal structure: A5 (anatase, $5 \mathrm{~nm}$ ), A15 (anatase, $15 \mathrm{~nm}$ ) and AR20 (anataserutile, $20 \mathrm{~nm}$ ). The oxidative stress was determined by flow cytometry using the fluorescent probe CellROX $®$ green. ${ }^{[50]}$ The error bars represent the standard deviation of three independent replicates. Different letters indicate statistically significant differences and were obtained by Student-Newman-Keuls test with $p<0.05$. Cells exposed in the absence of $\mathrm{TiO}_{2} \mathrm{NPs}$ were used as negative control (NC). $\mathrm{TiO}_{2} \mathrm{NPs}$ caused oxidative stress in the algal cells in comparison with the unexposed negative control (5\%), with 11.49 to $21.47 \%$ of cells affected. TiO NPs - induced oxidative stress was primary size-dependent. However, no concentration dependence was found for AR20.

observed for $P$. subcapitata $(<2 \%$ cells) and $C$. reinhardtii $(<$ $22 \%$ ), suggesting the antioxidant systems were able to cope with the oxidative stress. Finally, the combination of $\mathrm{ZnONPs}^{[52]}$ or $\mathrm{CuONPs}^{[53]}$ with UV radiation resulted in synergistic effects on oxidative stress and membrane damage, which were attributed to the important ion release from NPs. Comparative study of AgNPs and ionic silver showed that both silver forms affected viability of C. reinhardtii, but only ionic silver-induced ROS production. [54]

Exposure to high concentrations of $\mathrm{TiO}_{2}$, silicon dioxide $\left(\mathrm{SiO}_{2}\right)$ and ZnONPs provokes DNA damage in the diatom Dunaliella tertiolecta. However, associated mechanisms were nanoparticle composition dependent: ZnONPs induced significant DNA strand breaks through the release of $\mathrm{Zn}^{2+} ; \mathrm{SiO}_{2} \mathrm{NPs}$ through excessive ROS generation; and $\mathrm{TiO}_{2} \mathrm{NPs}$ indirectly via activation of cellular signals involved in cell division or cell wall destruction. ${ }^{[55]}$ ENPs were shown to form complexes with DNA in vitro, which could alter DNA conformation, and induce DNA degradation. ${ }^{[56]}$ Similarly, ENPs form complexes with proteins, which could alter protein conformation and activity, and in turn impact cellular function. ${ }^{[57]}$ For example, metallothionein adsorbed on $20 \mathrm{~nm}$ citrate-coated AgNPs and promoted their dissolution; ceruloplasmin formed stable protein corona with a limited substitution of Cu. ${ }^{[58]}$ One study on mixtures of AgNPs and AuNPs with catalase (CAT) revealed that CAT formed complexes with AgNPs but not with AuNPs. The formation of the AgNPs-CAT complex resulted in losses of CAT quaternary structure, as well as in decrease of Ag ions released by AgNPs (Fig. 4). Despite the existing progress towards understanding the processes governing NP-biomolecule interactions, ${ }^{[59]}$ various issues mainly related to the underlying mechanism, time evolution of the formation of NP-biomolecule complexes in biological media and long-term effects to organisms are still to be resolved.

\section{Impact of Phytoplankton on ENPs Occurrence and Fate in the Aquatic Environment}

Phytoplankton species can affect the ENPs occurrence and fate in the aquatic environment directly by: (i) producing metallic nanoparticles from dissolved metals ions, (ii) inducing transfor- 


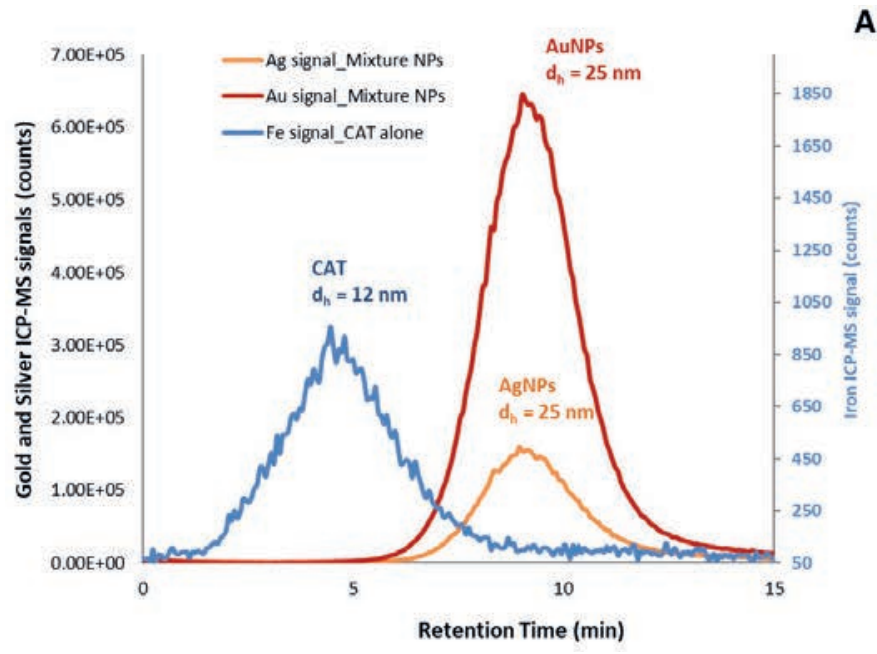

A

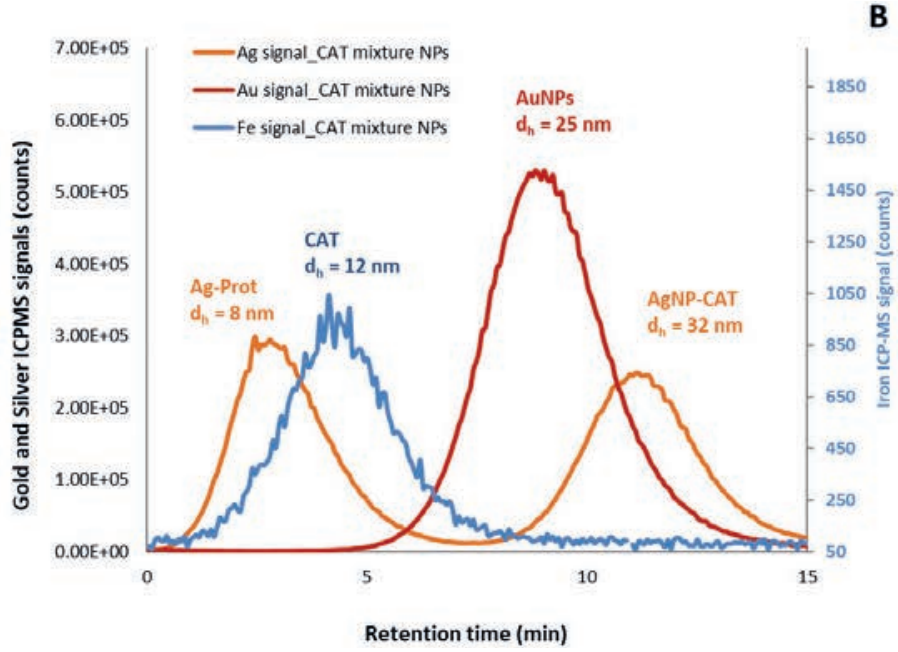

Fig. 4. Interaction between $20 \mathrm{~nm}$ citrate-coated AuNPs, AgNPs, and catalase (CAT, iron (Fe) co-factor) over $24 \mathrm{~h}$ in vitro incubation. The use of asymmetrical flow field-flow fractionation coupled on-line to inductively coupled plasma mass spectrometry (AF4-ICPMS) allowed to separate metallic nano-objects according to their hydrodynamic diameter $\left(d_{h}\right)$ which increases with retention time. (A) Mixture of AgNPs and AuNPs. The Au and Ag signals maxima correspond to an average $\mathrm{d}_{\mathrm{h}}$ of $25 \mathrm{~nm}$. The Ag signal was low indicating the dissolution of AgNPs. The Fe signal of CAT in the absence of NPs is also detected (blue line). (B) Mixture of AgNPs and AuNPs in presence of CAT. No change in the $d_{h}$ of AuNPs $\left(d_{h}=25\right.$ nm at the maximum Au signal) nor the Au content was observed, showing no complexation between AuNPs and CAT. An increase of $d_{h}$ of AgNPs from 25 to $32 \mathrm{~nm}$ and an increase of the Ag signal indicated complex formation between AgNPs and CAT resulting in formation of CAT-corona on the AgNPs and decrease of the dissolution of AgNPs.

mation of ENPs inside the cells or at the cell surface; and indirectly by (iii) secreting different small molecules and extracellular polymeric substances (EPS).

\subsection{Production of Nanoparticles by Phytoplankton}

Phytoplankton species were shown to produce NPs extra- or intra-cellularly.[60] Different phytoplankton species, including $C$. reinhardtii, ${ }^{[61]}$ Chlorella sp., Coelastrum sp., Scenedesmus sp., ${ }^{[62]}$ Chlorella vulgaris, ${ }^{[63]}$ Tetraselmis kochinensis, ${ }^{[64]}$ were shown to produce AgNPs, AuNPs or ZnONPs. AuNPs with sizes of 5-35 nm were produced intracellularly by $T$. kochinensis. ${ }^{[64]}$ Highly stable AgNPs with average sizes of $5-10 \mathrm{~nm}$ were generated by Scenedesmus sp. ${ }^{\text {62a] }}$ Several possible mechanisms of nanoparticle synthesis by phytoplankton were proposed ${ }^{[61,62,63 \mathrm{c}]}$ including: (i) trapping of metal ions on the surface of algal cell, (ii) accumulation of metal inside the cytoplasm and nucleus; (iii) enzymatic reduction of intracellular metals ions, simultaneous growth and accumulation of nuclei to particles; (iv) strong binding of amino acid residues of proteins with nanoparticles.

\subsection{Phytoplankton-mediated Transformations of ENPs}

Recent studies demonstrated that green algae transform internalized ENPs. ${ }^{[65]}$ Processes of intracellular reduction, sulfidation and complexation by intracellular ligands were reported to be involved in ENPs transformations. For example, CuONPs sulfidation to $\mathrm{CuS}$ and direct reduction of $\mathrm{CuS}$ to $\mathrm{Cu}_{2} \mathrm{ONPs}$, involving ferredoxin as electron donor were shown in Chlorella pyrenoidosa. ${ }^{[66]}$ Transformation of AgNPs to Ag0, Ag-glutathione complex and $\mathrm{Ag}_{2} \mathrm{~S}$ was demonstrated in $C$. reinhardtii. The underlying mechanism probably involves dissolution-sulfidation-reduction, including precipitation of released ions with sulfide followed by a reductive transformation. ${ }^{[67]}$ The cellular transformations of ENPs by other phytoplankton species are to be demonstrated and improving the knowledge on the principal transformation mechanisms will be of great interest in future research.

\subsection{Influence of Phytoplankton Exudates on ENPs}

Phytoplankton excrete a large variety of small molecules, nucleic acid, fatty acid, carbohydrates polymers and proteins which form their secretome and modulate the stability of ENPs. ${ }^{[68]}$ For example, exudates secreted from the cyanobacterium Synechocystis sp. efficiently stabilized $20 \mathrm{~nm}$ and $50 \mathrm{~nm}$ citrate-coated AgNPs and lipoic acid-coated AgNPs, but had a minor effect on the PVP-coated AgNPs of similar size, ${ }^{[68 c]}$ showing the importance of the primary surface coating of ENPs. Exudates released from Chlorella sp. decreased the release of $\mathrm{Zn}^{2+}$ ions from $\mathrm{ZnONPs}$, ${ }^{699]}$ as did EPS isolated from cyanobacterial bloom. ${ }^{[70]}$ Moreover, polysaccharides were shown to be involved in the formation of AgNPs in cell-free culture liquid extracts of individual cultures of 14 different strains of cyanobacteria and microalgae.[62b] The above examples demonstrate the important role of the phytoplankton secretome in ENP stability.

\section{Conclusions and Outlook}

Understanding the environmental implications of nanotechnology requires bridging environmental chemistry and ecotoxicology. In the past 15 years, significant progress was made to understand ENPs exposure, uptake and toxico- availabilities to aquatic organisms, including phytoplankton, and to identify different modifying factors. Nevertheless, the kinetic aspects underlying different processes are still to be elucidated. Recently it was proposed to incorporate the time-dependent size distribution of dispersed and internalized ENPs in the bioavailability modelling. ${ }^{[12]}$ The influence of phytoplankton on ENPs fate in aquatic environments has received much less attention despite significant recent advances. In addition, most of the existing results were obtained with single phytoplankton species in well-controlled media with relatively high concentrations of ENPs, so the possible effects to the phytoplankton communities under natural conditions have yet to be demonstrated.

A major challenge remains to understand the behavior and impacts of ENPs in combination with other environmental stressors (light, temperature, etc.) and different contaminants. Different types of interactions - synergistic, additive, and antagonistic have been highlighted in the case of trace metals and light.[71] Understanding the influence of the climate change on the environmental fate and effects of ENPs is also an important question for future research. Therefore, a more systematic approach taking into account the combined pressure of multiple stressors ${ }^{[72]}$ and reconceptualization of exposure and effects of chemical cocktails containing ENPs will be a central topic for the future nanoecotoxicology agenda. 
Rapid development of '-omics' technologies opened novel avenues towards elucidating contaminant modes-of-action. ${ }^{[73]}$ Very recent results of '-omics' approaches demonstrated that ENPs alter expression of genes related to photosynthesis, lipid biosynthesis and cell proliferation in alga. ${ }^{[65]} \mathrm{TiO}_{2} \mathrm{NPs}_{\text {induced a }}$ dysregulation of the genes involved in the algal photosynthesis, which underlines the contribution of metabolic disturbances, and emphasized the threat to photosynthesis. ${ }^{[74]}$ Metabolic profiling of Chlorella vulgaris demonstrated significant changes in a number of metabolites involved in redox metabolism upon exposure to carbon nanotubes. ${ }^{[75]}$ The role of '-omics' in nanoecotoxicology undoubtedly will increase in future and will significantly contribute unraveling the mode of action of ENPs and developing the mechanism-based predictive risk assessment approaches. Understanding the interactions of ENPs with living systems is central for assessing the ways in which humanity is continuously changing our environment as well as for promoting the sustainable and environmentally friendly nanotechnology.

\section{Acknowledgments}

V.I.S. acknowledges the financial support of the Swiss National Science Foundation (Grant number IZSEZ0_180186).

Received: November 29, 2019

[1] M. Knell, 'Nanotechnology and the Sixth Technological Revolution', 2011

[2] I. Capek, in 'Studies in Interface Science', Vol. 23, Ed. I. Capek, Elsevier 2006, p. 1, DOI: 10.1016/S1383-7303(06)80002-5

[3] E. Serrano, in 'Materials Today', Vol. 13, 2010, p. 55, DOI: 10.1016/S13697021(10)70089-4.

[4] a) V. L. Colvin, Nature Biotechnol. 2003, 21, 1166; b) S. J. Klaine, P. J. J. Alvarez, G. E. Batley, T. F. Fernandes, R. D. Handy, D. Y. Lyon, S. Mahendra, M. J. McLaughlin, J. R. Lead, Environ. Toxicol. Chem. 2008 27, 1825, DOI: 10.1897/08-090.1; c) B. Nowack, T. D. Bucheli, Environ. Pollution 2007, 150, 5, DOI: 10.1016/j.envpol.2007.06.006.

[5] O. Bondarenko, K. Juganson, A. Ivask, K. Kasemets, M. Mortimer, A Kahru, Arch. Toxicol. 2013, 87, 1181, DOI: 10.1007/s00204-013-1079-4.

[6] M. Nordberg, J. H. Duffus, D. M. Templeton, Pure Appl. Chem. 2010, 82, 679.

[7] S. Basu, K. Mackey, Sustainability 2018, 10, 869.

[8] E. Sakshaug, G. Johnsen, S. Kristiansen, C. Quillfeldt, F. Rey, D. Slagstad, T. F. Thingstad, Ecosystem Barents Sea 2009, 167.

[9] a) M. Akter, M. T. Sikder, M. M. Rahman, A. Ullah, K. F. B. Hossain, S Banik, T. Hosokawa, T. Saito, M. Kurasaki, J. Adv. Res. 2018, 9, 1, DOI: 10.1016/j.jare.2017.10.008; b) P. A. Holden, J. L. Gardea-Torresdey, F Klaessig, R. F. Turco, M. Mortimer, K. Hund-Rinke, E. A. C. Hubal, D. Avery, D. Barcelo, R. Behra, Y. Cohen, L. Deydier-Stephan, P. L. Ferguson, T. F. Fernandes, B. H. Harthorn, W. M. Henderson, R. A. Hoke, D. Hristozov, J. M. Johnston, A. B. Kane, L. Kapustka, A. A. Keller, H. S. Lenihan, W. Lovell, C. J. Murphy, R. M. Nisbet, E. J. Petersen, E. R. Salinas, M. Scheringer, M. Sharma, D. E. Speed, Y. Sultan, P. Westerhoff, J. C. White, M. R. Wiesner, E. M. Wong, B. S. Xing, M. S. Horan, H. A. Godwin, A. E. Nel, Environ. Sci. Technol. 2016, 50, 6124, DOI: 10.1021/acs.est.6b00608; c) A. Ivask, K. Juganson, O. Bondarenko, M. Mortimer, V. Aruoja, K. Kasemets, I. Blinova, M. Heinlaan, V. Slaveykova, A. Kahru, Nanotoxicol. 2014, 8, 57, DOI: 10.3109/17435390.2013.855831; d) E. McGillicuddy, I. Murray, S. Kavanagh, L. Morrison, A. Fogarty, M. Cormican, P. Dockery, M. Prendergast, N. Rowan, D. Morris, Sci. Total Environ. 2017, 575, 231, DOI: 10.1016/j.scitotenv.2016.10.041; e) W. C. Zhang, B. D. Xiao, T. Fang, Chemosphere 2018, 191, 324, DOI: 10.1016/j.chemosphere.2017.10.016; f) E. Joonas, V. Aruoja, K. Olli, A. Kahru, Sci. Total Environ. 2019, 647, 973, DOI: 10.1016/j.scitotenv.2018.07.446; g) R. Kumar, A. Umar, G. Kumar, H. S. Nalwa, Ceramics Int. 2017, 43, 3940, DOI: 10.1016/j.ceramint.2016.12.062; h) J. R. Lead, G. E. Batley, P. J. J. Alvarez, M. N. Croteau, R. D. Handy, M. J. McLaughlin, J. D. Judy, K. Schirmer, Environ. Toxicol. Chem. 2018, 37, 2029, DOI: 10.1002/etc.4147.

[10] a) N. von Moos, P. Bowen, V. I. Slaveykova, Environ. Sci.: Nano 2014, 1, 214, DOI: 10.1039/C3EN00054K; b) V. Slaveykova, B. Sonntag, J. C. Gutiérrez, Eur. J. Protistology 2016, 55, 39, DOI: 10.1016/j.ejop.2016.06.001.

[11] S. Ma, D. H. Lin, Environ. Sci: Processes \& Impacts 2013, 15, 145, DOI: $10.1039 / \mathrm{c} 2 \mathrm{em} 30637 \mathrm{a}$.

[12] M. G. Vijver, Y. J. Zhai, Z. Wang, W. Peijnenburg, Environ. Sci: Nano 2018 5, 2473, DOI: 10.1039/c8en00572a.

[13] a) M. Baalousha, Nanoimpact 2017, 6, 55, DOI: 10.1016/j.impact.2016.10.005; b) P. Christian, F. Von der Kammer, M. Baalousha, T. J.
E. Hofmann, Ecotoxicol. 2008, 17, 326; c) G. V. Lowry, K. B. Gregory, S. C. Apte, J. R. Lead, Environ. Sci. Technol. 2012, 46, 6893, DOI: 10.1021/ es300839e.

[14] a) C. Peng, W. Zhang, H. Gao, Y. Li, X. Tong, K. Li, X. Zhu, Y. Wang, Y. Chen, Nanomater. 2017, 7, DOI: 10.3390/nano7010021; b) R. Wang, F. Dang, C. Liu, D.-j. Wang, P.-x. Cui, H.-j. Yan, D.-m. Zhou, Environ. Sci.: Nano 2019, 6, 195, DOI: 10.1039/c8en00543e; c) Z. Liu, C. Wang, J. Hou, P. Wang, L. Miao, B. Lv, Y. Yang, G. You, Y. Xu, M. Zhang, H. Ci, Environ. Sci. Pollution Res. 2018, 25, 31240, DOI: 10.1007/s11356-018-3123-7.

[15] a) L. A. Ellis, M. Baalousha, E. Valsami-Jones, J. R. Lead, Chemosphere 2018, 191, 616, DOI: 10.1016/j.chemosphere.2017.10.006; b) M. C. Surette, J. A. Nason, Environ. Sci.: Nano 2019, 6, 540, DOI: 10.1039/c8en01021h; c) A. Clavier, A. Praetorius, S. Stoll, Sci. Total Environ. 2019, 650, 530, DOI: 10.1016/j.scitotenv.2018.09.017; d) O. Oriekhova, S. Stoll, Sci. Total Environ. 2019, 648, 1171, DOI: 10.1016/j.scitotenv.2018.08.176.

[16] a) S. M. Louie, R. D. Tilton, G. V. Lowry, Environ. Sci.: Nano 2016, 3, 283, DOI: 10.1039/c5en00104h; b) G. E. Schaumann, A. Philippe, M. Bundschuh, G. Metreveli, S. Klitzke, D. Rakcheev, A. Grun, S. K. Kumahor, M. Kuhn, T. Baumann, F. Lang, W. Manz, R. Schulz, H. J. Vogel, Sci. Total Environ. 2015, 535, 3, DOI: 10.1016/j.scitotenv.2014.10.035.

[17] a) S. N. Sørensen, C. Engelbrekt, H.-C. H. Lützhøft, J. Jiménez-Lamana, J. S. Noori, F. A. Alatraktchi, C. G. Delgado, V. I. Slaveykova, A. Baun, Environ. Sci. Technol. 2016, 50, 10635, DOI: 10.1021/acs.est.6b01072; b) N. H. A. Nguyen, V. V. T. Padil, V. I. Slaveykova, M. Černík, A. Ševců, Nanoscale Res. Lett. 2018, 13, 159, DOI: 10.1186/s11671-018-2575-5.

[18] N. H. A. Nguyen, N. R. Von Moos, V. I. Slaveykova, K. Mackenzie, R. U. Meckenstock, S. S. Thümmler, J. Bosch, A. Ševců, Ecotoxicol. Environ. Safety 2018, 154, 36, DOI: 10.1016/j.ecoenv.2018.02.027.

[19] Y. Yue, X. M. Li, L. Sigg, M. J. F. Suter, S. Pillai, R. Behra, K. Schirmer, J. Nanobiotechnol. 2017, 15, DOI: 10.1186/s12951-017-0254-9.

[20] A. G. Gonzalez, O. S. Pokrovsky, I. S. Ivanova, O. Oleinikova, A. FeurtetMazel, S. Mornet, M. Baudrimont, Minerals 2018, 8, DOI: 10.3390/ $\min 8030099$.

[21] B. Sottocasa, University of Geneva, Geneva, 2012.

[22] T. C. Dakal, A. Kumar, R. S. Majumdar, V. Yadav, Front. Microbiol. 2016, 7 , DOI: $10.7389 /$ fmicb.2016.01831.

[23] I. A. M. Worms, J. Boltzman, M. Garcia, V. I. Slaveykova, Environ. Pollution 2012, 167, 27, DOI: 10.1016/j.envpol.2012.03.030.

[24] N. von Moos, V. I. Slaveykova, Nanotoxicol. 2014, 8, 605, DOI: 10.3109/17435390.2013.809810.

[25] A.-J. Miao, Z. Luo, C.-S. Chen, W.-C. Chin, P. H. Santschi, A. Quigg, PLoS ONE 2010, 5, e15196, DOI: 10.1371/journal.pone.0015196.

[26] Y. Wang, A. J. Miao, J. Luo, Z. B. Wei, J. J. Zhu, L. Y. Yang, Environ. Sci. Technol. 2013, 47, 10601, DOI: 10.1021/es4017188.

[27] C. Cherchi, T. Chernenko, M. Diem, A. Z. Gu, Environ. Toxicol. Chem. 2011, 30, 861, DOI: Doi 10.1002/Etc.445.

[28] L. Z. Chen, L. N. Zhou, Y. D. Liu, S. Q. Deng, H. Wu, G. H. Wang, Ecotoxicol. Environ. Safety 2012, 84, 155, DOI: DOI 10.1016/j.ecoenv.2012.07.019.

[29] F. Perreault, A. Oukarroum, S. P. Melegari, W. G. Matias, R Popovic, Chemosphere 2012, 87, 1388, DOI: DOI 10.1016/j.chemosphere.2012.02.046.

[30] F. Perreault, N. Bogdan, M. Morin, J. Claverie, R. Popovic, Nanotoxicol. 2012, 6, 109, DOI: doi:10.3109/17435390.2011.562325.

[31] M. Sendra, M. P. Yeste, J. M. Gatica, I. Moreno-Garrido, J. Blasco, Chemosphere 2017, 179, 279, DOI: 10.1016/j.chemosphere.2017.03.123.

[32] a) F. Piccapietra, C. G. Allué, L. Sigg, R. Behra, Environ. Sci. Technol. 2012, 46, 7390, DOI: 10.1021/es300734m; b) S. Pillai, R. Behra, H. Nestler, M. J.F. Suter, L. Sigg, K. Schirmer, Proc. Natl Acad. Sci. 2014, 111, 3490, DOI: 10.1073/pnas.1319388111.

[33] R. C. Merrifield, C. Stephan, J. R. Lead, Environ. Sci. Technol. 2018, 52, 2271, DOI: $10.1021 /$ acs.est.7b04968.

[34] R. F. Domingos, D. F. Simon, C. Hauser, K. J. Wilkinson, Environ. Sci. Technol. 2011, 45, 7664, DOI: Doi 10.1021/Es201193s.

[35] H. Ma, P. L. Williams, S. A. Diamond, Environ. Pollution 2013, 172, 76, DOI: 10.1016/j.envpol.2012.08.011.

[36] a) C. Y. Wang, D. Y. Lyon, J. B. Hughes, G. N. Bennett, Environ. Sci. Technol. 2003, 37, 3595; b) E. Navarro, A. Baun, R. Behra, N. B. Hartmann, J. Filser, A. J. Miao, A. Quigg, P. H. Santschi, L. Sigg, Ecotoxicol. 2008, 17, 372, DOI: 0.1007/s10646-008-0214-0; c) Z. Y. Wang, J. Li, J. Zhao, B. S. Xing, Environ. Sci. Technol. 2011, 45, 6032, DOI: 10.1021/Es2010573.

[37] D. Medlin, G. Snyder, J. Curr. Opin. Colloid \& Interface Sci. 2009, 14, 226.

[38] C. Santschi, N. Von Moos, V. B. Koman, V. I. Slaveykova, P. Bowen, O. J. F. Martin, J. Nanobiotechnol. 2017, 15, 19, DOI: 10.1186/s12951-017-0253-x.

[39] Q. Mu, G. Jiang, L. Chen, H. Zhou, D. Fourches, A. Tropsha, B. Yan, Chem Rev. 2014, 114, 7740, DOI: $10.1021 / \mathrm{cr} 400295$ a.

[40] M. Schieber, N. S. J. C. b. Chandel, Curr. Biol. 2014, 24, R453.

[41] H. Ma, P. L. Williams, S. A. J. E. P. Diamond, Environ. Pol. 2013, 172, 76.

[42] C. H. D. Costa, F. Perreault, A. Oukarroum, S. P. Melegari, R. Popovic, W. G. Matias, Sci. Total Environ. 2016, 565, 951, DOI: 10.1016/j.scitotenv.2016.01.028.

[43] T. Y. Suman, S. R. Radhika Rajasree, R. Kirubagaran, Ecotoxicol. Environ. Safety 2015, 113, 23, DOI: 10.1016/j.ecoenv.2014.11.015. 
[44] F. Ahmad, H. Yao, Y. Zhou, X. Liu, Chemosphere 2015, 139, 479, DOI: 10.1016/j.chemosphere.2015.08.008.

[45] B. Xia, B. Chen, X. Sun, K. Qu, F. Ma, M. Du, Sci. Total Environ. 2015, 508 525, DOI: 10.1016/j.scitotenv.2014.11.066.

[46] F. Li, Z. Liang, X. Zheng, W. Zhao, M. Wu, Z. Wang, Aquatic Toxicol. 2015 , 158, 1, DOI: 10.1016/j.aquatox.2014.10.014.

[47] R. Roy, A. Parashar, M. Bhuvaneshwari, N. Chandrasekaran, A. Mukherjee, Aquatic Toxicol. 2016, 176, 161.

[48] J. Jiang, G. Oberdörster, A. Elder, R. Gelein, P. Mercer, P. Biswas, Nanotoxicol. 2008, 2, 33, DOI: 10.1080/17435390701882478.

[49] H. Schug, C. W. Isaacson, L. Sigg, A. A. Ammann, K. Schirmer, Environ. Sci. Technol. 2014, 48, 11620, DOI: 10.1021/es502620e.

[50] G. Cheloni, C. Cosio, V. I. Slaveykova, Aquatic Toxicol. 2014, 155, 275, DOI: 10.1016/j.aquatox.2014.07.010

[51] C. Kaweeteerawat, A. Ivask, R. Liu, H. Zhang, C. H. Chang, C. Low-Kam, H. Fischer, Z. Ji, S. Pokhrel, Y. Cohen, D. Telesca, J. Zink, L. Mädler, P. A Holden, A. Nel, H. Godwin, Environ. Sci. Technol. 2015, 49, 1105, DOI: 10.1021/es504259s.

[52] M. Bhuvaneshwari, V. Iswarya, S. Archanaa, G. M. Madhu, G. K. S. Kumar R. Nagarajan, N. Chandrasekaran, A. Mukherjee, Aquatic Toxicol. 2015, 162, 29, DOI: 10.1016/j.aquatox.2015.03.004.

[53] G. Cheloni, E. Marti, V. I. Slaveykova, Aquatic Toxicol. 2016, 170, 120, DOI: 10.1016/j.aquatox.2015.11.018.

[54] L. M. Stevenson, H. Dickson, T. Klanjscek, A. A. Keller, E. McCauley, R. M Nisbet, PLoS One 2013, 8, e74456, DOI: 10.1371/journal.pone.0074456.

[55] S. Schiavo, M. Oliviero, M. Miglietta, G. Rametta, S. Manzo, Sci. Total Environ. 2016, 550, 619, DOI: 10.1016/j.scitotenv.2016.01.135.

[56] a) A. Kumar, A. K. Pandey, S. S. Singh, R. Shanker, A. Dhawan, Free Radic. Biol. Med. 2011, 51, 1872, DOI: 10.1016/j.freeradbiomed.2011.08.025; b) J. Liu, Phys. Chem. Chem. Phys. 2012, 14, 10485, DOI: 10.1039/c2cp41186e; c) R. Prado-Gotor, E. Grueso, Phys. Chem. Chem. Phys. 2011, 13, 1479, DOI: $10.1039 / \mathrm{c} 0 \mathrm{cp} 00901 \mathrm{f}$.

[57] a) S. R. Saptarshi, A. Duschl, A. L. Lopata, J. Nanobiotechnol. 2013, 11, 26; b) M. Zarei, J. Aalaie, Anal. Bioanal. Chem. 2019, 411, 79, DOI: 10.1007/ s00216-018-1401-3

[58] W. Liu, I. A. Worms, N. Herlin-Boime, D. Truffier-Boutry, I. Michaud-Soret, E. Mintz, C. Vidaud, F. Rollin-Genetet, Nanoscale 2017, 9, 6581.

[59] a) N. Bertrand, P. Grenier, M. Mahmoudi, E. M. Lima, E. A. Appel, F. Dormont, J.-M. Lim, R. Karnik, R. Langer, O. C. Farokhzad, Nature Commun. 2017, 8, 777, DOI: 10.1038/s41467-017-00600-w; b) T. Miclăuş, C. Beer, J. Chevallier, C. Scavenius, V. E. Bochenkov, J. J. Enghild, D. S. Sutherland, Nature Commun. 2016, 7, 11770, DOI: 10.1038/ncomms11770 https://www.nature.com/articles/ncomms11770\#supplementary information; c) A. E. Nel, L. Mädler, D. Velegol, T. Xia, E. M. V. Hoek, P. Somasundaran, F. Klaessig, V. Castranova, M. Thompson, Nature Mater 2009, 8, 543, DOI: 10.1038/nmat2442; d) M. Hadjidemetriou, K. Kostarelos, Nature Nanotechnol. 2017, 12, 288, DOI: 10.1038/nnano.2017.61; e) M. P. Monopoli, C. Åberg, A. Salvati, K. A. Dawson, Nature Nanotechnol. 2012, 7, 779, DOI: 10.1038/nnano.2012.207; f) S. Tenzer, D. Docter, J. Kuharev, A. Musyanovych, V. Fetz, R. Hecht, F. Schlenk, D. Fischer, K. Kiouptsi, C. Reinhardt, Nature Nanotechnol. 2013, 8, 772.

[60] P. Singh, Y. J. Kim, D. Zhang, D. C. Yang, Trends Biotechnol. 2016, 34, 588, DOI: 10.1016/j.tibtech.2016.02.006.

[61] a) I. Barwal, P. Ranjan, S. Kateriya, S. C. Yadav, J. Nanobiotechnol. 2011, 9 56; b) M. D. Rao, P. Gautam, Environ. Progr. Sust. Ener. 2016, 35, 1020.
[62] a) J. Jena, N. Pradhan, R. R. Nayak, B. P. Dash, L. B. Sukla, P. K. Panda, B. K. Mishra, J. Microbiol. Biotechnol. 2014, 24, 522; b) V. Patel, D. Berthold, P. Puranik, M. Gantar, Biotechnol. Rep. 2015, 5, 112.

[63] a) A. Ebrahiminezhad, M. Bagheri, S.-M. Taghizadeh, A. Berenjian, Y Ghasemi, Adv. Nat. Sci.: Nanosci. Nanotechnol. 2016, 7, 015018; b) J. Annamalai, T. Nallamuthu, Appl. Nanosci. 2015, 5, 603; c) T. Luangpipat, I. R. Beattie, Y. Chisti, R. G. Haverkamp, J. Nanoparticle Res. 2011, 13, 6439.

[64] S. Senapati, A. Syed, S. Moeez, A. Kumar, A. Ahmad, Mater. Lett. 2012, 79 , 116.

[65] F. Chen, Z. Xiao, L. Yue, J. Wang, Y. Feng, X. Zhu, Z. Wang, B. Xing, Environ. Sci.: Nano 2019, 6, 1026, DOI: 10.1039/C8EN01368C.

[66] J. Zhao, X. Cao, X. Liu, Z. Wang, C. Zhang, J. C. White, B. Xing, Nanotoxicol. 2016, 10, 1297, DOI: 10.1080/17435390.2016.1206149.

[67] S. Wang, J. Lv, J. Ma, S. Zhang, Nanotoxicol. 2016, 10, 1129, DOI: 10.1080/17435390.2016.1179809.

[68] a) A. Avellan, M. Simonin, E. McGivney, N. Bossa, E. Spielman-Sun, J. D. Rocca, E. S. Bernhardt, N. K. Geitner, J. M. Unrine, M. R. Wiesner, G. V. Lowry, Nature Nanotechnol. 2018, 13, 1072, DOI: 10.1038/s41565-0180231-y; b) X. Gao, K. J. Zhou, L. Q. Zhang, K. Yang, D. H. Lin, Environ. Sci.: Nano 2018, 5, 720, DOI: 10.1039/c7en01176h; c) J. Jiménez-Lamana, V. I. Slaveykova, Sci. Total Environ. 2016, 573, 946, DOI: 10.1016/j.scitotenv.2016.08.181.

[69] P. Chen, B. A. Powell, M. Mortimer, P. C. Ke, Environ. Sci. Technol. 2012, 46, 12178, DOI: 10.1021/es303303g.

[70] H. Xu, H. Jiang, Environ. Pollution 2015, 197, 231, DOI: 10.1016/j.envpol.2014.10.031

[71] a) G. Cheloni, V. Slaveykova, Environments 2018, 5, 81; b) B. B. Fischer, F. Pomati, R. I. L. Eggen, Sci. Total Environ. 2013, 449, 253, DOI: 10.1016/j. scitotenv.2013.01.066

[72] S. S. Kaushal, A. J. Gold, S. Bernal, T. A. N. Johnson, K. Addy, A. Burgin, D. A. Burns, A. A. Coble, E. Hood, Y. H. Lu, P. Mayer, E. C. Minor, A. W. Schroth, P. Vidon, H. Wilson, M. A. Xenopoulos, T. Doody, J. G. Galella, P. Goodling, K. Haviland, S. Haq, B. Wessel, K. L. Wood, N. Jaworski, K. T. Belt, Biogeochem. 2018, 141, 281, DOI: 10.1007/s10533-018-0502-6.

[73] S. J. Sturla, A. R. Boobis, R. E. FitzGerald, J. Hoeng, R. J. Kavlock, K. Schirmer, M. Whelan, M. F. Wilks, M. C. Peitsch, Chem. Res. Toxicol. 2014, 27, 314, DOI: 10.1021/tx400410s.

[74] A. Middepogu, J. Hou, X. Gao, D. Lin, Ecotoxicol. Environ. Safety 2018, 161, 497, DOI: 10.1016/j.ecoenv.2018.06.027.

[75] X. Hu, S. Ouyang, L. Mu, J. An, Q. Zhou, Environ. Sci. Technol. 2015, 49, 10825, DOI: 10.1021/acs.est.5b02102.

\section{License and Terms}

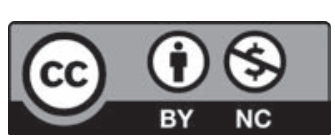

This is an Open Access article under the terms of the Creative Commons Attribution License CC BY_NC 4.0. The material may not be used for commercial purposes.

The license is subject to the CHIMIA terms and conditions: (http:// chimia.ch/component/sppagebuilder/?view=page\&id=12).

The definitive version of this article is the electronic one that can be found at doi:10.2533/chimia.2020.115 